\title{
TRENDS IN PERSONAL INJURY LITIGATION: THE 1990S
}

\author{
John Miller*
}

Just as Accident Compensation did not exist in a political or social vacuum, it also did not exist in a legal vacuum. One of the remarkable features of the last decade has been the resurgence of personal injury actions, partially as a response to the scheme being perceived as less generous. John Miller details case law development over the last decade or so.

The Accident Rehabilitation and Compensation Insurance Act 1992 came into force on 1 July 1992 and caused a substantial increase in common law damages claims being brought by injured persons.

Prior to that Act there had been a steady decline in common law damages claims as (1) pre 1 April 1974 accident claims were gradually settled and (2) the bar in the ACC Acts of 1972 and 1982 on bringing proceedings for damages stopped most damages claims for injuries arising from 1 April 1974 onwards.

To be sure there was still some litigation on post-1974 accidents as the limits of the scheme were tested particularly on whether exemplary damages could still be claimed but by the 1980s that issue had also been clarified. ${ }^{1}$

However the 1992 Act was a move from "a more generous scheme to a less generous compensation scheme", 2 and brought in many changes to the scheme which refuelled litigation.

\section{CHANGES IN 1992}

\section{A Lump Sums Abolished}

One of the most significant changes was abolishing lump sum payments of up to $\$ 27,000$ for permanent impairment and replacing them with a meagre independence allowance of $\$ 40$ per week. Prior to its repeal in 1992 the Accident Compensation Act 1982 had two lump sums available in

* Barrister, Wellington and Senior Lecturer in Law, Victoria University of Wellington.

1 Donselaar v Donselaar [1982] 1 NZLR 97 (CA).

2 Childs $v$ Hillock [1994] 2 NZLR 65, 68 (CA). 
cases of permanent impairment. There was a lump sum of $\$ 17,000$ for the physical impairment. That was paid out on an objective percentage basis. For example the loss of a leg was 75 per cent of $\$ 17,000$, the loss of an eye was 30 per cent. There was also another lump sum of $\$ 10,000$ payable for pain suffering and loss of amenities.

The loss of a lump sum was felt particularly by non-earners, as a lump sum had hitherto been the only tangible financial recognition of their loss. They were not entitled to weekly compensation as that had to be based on earnings received immediately prior to the accident.

For example prior to the 1992 Act a victim of sexual violation who was a non-earner would not receive weekly compensation but would at least receive the lump sum of $\$ 10,000$ for pain and suffering. Furthermore if a psychiatric report indicated some form of residual impairment in the nature of a post traumatic stress disorder then a percentage amount (usually 20 per cent to 45 per cent) of the lump sum of $\$ 17,000$ could be paid as well.

Thus there was some recognition of the harm done to that person by the award of approximately $\$ 17,650(\$ 10,000+45$ per cent of $\$ 17,000=\$ 7,650)$.

When this was contrasted with an independence allowance award of $\$ 40$ per week even for a 100 per cent impairment it was perceived as an insult and a complete non-recognition of the injury.

Another group hit hard by the removal of lump sums were those accident victims who had only a short time to live. This was a common feature in asbestos related claims such as mesothelioma. By the time such a work related disease had manifested itself the injured worker was usually retired and therefore had no earnings from which to receive weekly compensation. Furthermore they invariably had only a short time (six to twelve months) to live. To be told that their compensation would now be an independence allowance of a maximum sum of $\$ 40$ per week for those six months instead of a lump sum of up to $\$ 27,000$ was particularly galling.

This then led those who would have previously been satisfied by a lump sum award to approach lawyers for advice on alternative means of gaining compensation. Thus once again lawyers, after a gap of 18 years, had to start turning their minds to common law damages claims.

\section{B Mental Injury Restricted}

Another major change in the 1992 Act, which also fueled litigation, was the removal of nervous shock claims from ACC cover. Thus Law Schools had to start teaching the law of nervous shock in tort law courses again after a gap of 18 years.

The Accident Compensation Acts of 1972 and 1982 had covered the physical and mental consequences of the injury or of the accident. Mental consequences had been interpreted to cover 
transient mental trauma such as anger, embarrassment, humiliation and distress as well as the more serious psychiatric aliments. ${ }^{3}$

Also under the 1972 and 1982 Acts the mental consequences could come from the accident - the untoward event. Thus there was no need for the person suffering nervous shock to be physically injured. Viewing a horrific event was sufficient. In Cochrane $v A C C^{4}$ the claimant watched her son die in hospital after he had been tortured by a gang. She was not physically injured but suffered a disordered grief reaction and was covered by the 1982 Act.

However the 1992 Act restricted the mental injury covered by the ACC to a "clinically significant behavioural, cognitive or psychological dysfunction". Thus transient emotional trauma was no longer covered.

Furthermore apart from a mental injury caused by sexual abuse the 1992 Act required that the mental injury be an outcome of physical injuries to the person concerned.

Thus nervous shock claims where there had been no physical injury were excluded from the Act. So too were claims for mental injury which had arisen from the circumstances of the event rather than any physical injury. In one case a young woman had been bruised through being tied up during a robbery. She suffered post traumatic stress disorder (PTSD) which was accepted by the ACC as a mental injury and the bruising was also accepted as a physical injury however her claim for PTSD was declined as that came from the frightening events and not the bruising.

As there was no longer any ACC cover for such victims they also started to seek legal advice as to how they could gain compensation.

\section{Definitions}

Various definitions in the 1992 Act were couched in restrictive terms compared to the previous Acts. For example the definition of accident in the 1992 Act was defined to counteract interpretations made by the Courts of the definition of personal injury by accident in the previous Acts. In $A C C v$ Mitchell $^{5}$ a baby had suffered brain damage from inexplicably and suddenly ceasing to breathe. The Court of Appeal accepted this event had cover under the 1982 Act as a personal injury by accident. This was now excluded by the 1992 Act, as the definition of accident in the 1992 Act now required proof of an application of force or resistance external to the human body. Furthermore the mere fact that a personal injury had occurred was not to be considered as being caused by an accident. These and other changes to the definitions also led excluded claimants to seek legal advice.

\footnotetext{
3 Green v Matheson [1989] 3 NZLR 564 (CA).

4 Cochrane v ACC [1994] NZAR 6 (CA).

5 ACC v Mitchell [1992] 2 NZLR 436 (CA).
} 


\section{Work Related Gradual Process Disease and Infection}

Another area that caused dissatisfaction was that work related gradual process disease and infection claims became increasingly difficult to establish under the 1992 Act. The Act introduced a strict three-stage test and also excluded injuries related to non-physical stress and diseases attributable to passive smoking or air-conditioning.

This again meant that common law damages claims were now the only remedies for work related stress claims, passive smoking and illnesses such as Legionnaires disease contracted from defective air conditioning systems.

\section{E Medical Misadventure}

Another restrictive area, which fuelled dissatisfaction, was the tests introduced by the 1992 Act for medical misadventure. Medical misadventure was divided into two categories: medical error (in effect, negligence) and medical mishap. Medical mishap was defined to occur where there had been no negligence in providing the medical treatment but nevertheless there had been a rare and severe adverse consequence from the medical treatment.

The legislation defined a rare adverse consequence as one happening in one per cent or less of cases. That was a very low figure and there were many aggrieved claimants who were excluded from cover because their injury occurred in slightly over one per cent of cases.

Furthermore in the 1972 and 1982 Acts ACC cover could be given separately for personal injury by accident or medical misadventure. However in the 1992 Act if medical treatment was involved cover could only be given through medical misadventure and not through an accident. Thus in one case a woman undergoing a caesarian delivery burst into flames because the cutting instrument ignited the antiseptic fluid on the woman's skin. If this had happened outside a hospital there would have been no question that it was a personal injury covered by accident. However as it had happened during medical treatment the inquiry had to be made whether there was medical error or mishap. If there was no error and over one per cent of people undergoing medical operations burst into flames then the woman would have been left without cover. Such inquiries also take time particularly if the medical professional disputes the issue of medical error. Meanwhile the injured woman would be without ACC cover and entitlements. Such cases again caused injured claimants to seek legal advice on alternative remedies.

In some case the resort to common law damages was assisted by the Medical Misadventure Committees set up under the 1992 Act. Although they took some time to make a decision a finding of medical error was very helpful in negotiating a settlement to a common law damages claim.

\section{F Cessation on Account of Age}

The 1992 Act also caused widespread dissatisfaction amongst the elderly in that it reduced the cessation age for those already receiving weekly compensation under the previous ACC Acts from 
age 65 to the National Superannuating Qualifying Age (NSQA). The NSQA for those born between 1932 and 1936 was 60-64. Thus many permanently injured claimants who had been receiving weekly compensation and had organised their affairs and mortgages suddenly found that their weekly compensation would cease much earlier. This led claimants to consult their lawyers as to possible remedies. ${ }^{6}$

\section{G Long term Claimants - Work Capacity Procedures}

Another area of immense dissatisfaction created by the 1992 Act was the removal of long term claimants from the scheme through a variety of methods, the most notorious being the work capacity procedures. These procedures, which really started to be used by the ACC in the mid 1990s, assessed the still incapacitated claimant's suitability for work. If an occupational assessor and a medical assessor considered them to be suitable for any work for 30 hours a week or more they were deprived of their weekly compensation. This was so even though there was no actual work available and even if the work the claimant was assessed as capable of doing was at a much lower skill and income level than what the claimant had been doing previously. Assessments that a claimant had the suitability to be carpark or rubbish tip attendant seemed to be a favourite assessment by ACC assessors.

Furthermore the ACC only took into account the covered injury in making their assessments and not non-covered impairments. Thus a man with a back injury was nevertheless assessed as being capable of working as a salesman even though he had a pronounced stutter. ${ }^{7}$ In another case a man in his late $50 \mathrm{~s}$ with an injured knee was still assessed as having the capacity to work as a fitness instructor even though he also had 2 replaced hips, chronic pain, brucellosis and a heart condition. ${ }^{8}$

Many claimants saw the work capacity procedures as simply being a device to stop them from receiving weekly compensation. The use of the words "tail" and "stock" by the ACC in describing long-term claimants only increased dissatisfaction. The number of long-term claimants did decrease by the use of work capacity and other procedures from around 30000 to 16000 in the late 1990 s.

\section{H Rigid Regulations}

The 1992 Act also removed the ACC's discretions in providing rehabilitation and other entitlements. Instead rigid regulations covering all entitlements were introduced. This led to more dissatisfaction. For example the provision of attendant care for the seriously injured which had been open ended under the previous Acts was now limited by regulation to a maximum of $\$ 350$ per week which at a rate of $\$ 10$ per hour covered 35 hours care a week. This meant that those who were so

6 See ARCIC $v$ Watton (10 April 2000) Court of Appeal CA 277/99 for the result.

7 Kenyon v ACC (19 December 2001) High Court Wellington AP 258/00 Fisher J.

8 Alsig v ACC (21 March 2001) District Court Wellington 54/01 Barber J. 
seriously injured that they needed 24 hour a day care - 168 hours a week - were deprived of paid care for 133 hours a week. Amendments were made in 1996 to cure this and some other problems but other rigidities remained and continued to cause dissatisfaction.

\section{Other factors Fuelling Damages Litigation}

In addition to the "meaner and leaner" 1992 Act there were other factors in the 1990s fuelling damage litigation. There was dissatisfaction with medical disciplinary proceedings, which seemed to many patients to take too long with inadequate penalties imposed.

There was also the dissatisfaction of many crime victims with criminal proceedings. Many victims considered that they lost control of the proceedings where the State became the prosecutor and the victim was relegated to the role of a witness. Victims found themselves un-represented by counsel unlike the defendant. This made the option of civil proceedings more attractive. The victim was represented by counsel and had control of the proceedings. An example of this trend was shown by $G v G^{9}$ where exemplary damage proceedings were taken for domestic and sexual abuse rather than a prosecution.

\section{J Dissatisfaction Fuelled Search for Alternative Compensation}

The dissatisfaction created by the 1992 Act caused injured people to consult lawyers for alternative means of compensation.

Lawyers therefore had to be proactive in researching this area as careless advice on their part could lead to a negligence claim against them. Furthermore the Limitation Act 1950 only allowed two years in which to bring a personal injury claim as of right so time was of the essence.

\section{K Overseas Claims}

Some claimants with asbestos related diseases from overseas products were advised to bring claims overseas particularly in the Dust Diseases Tribunal of New South Wales where the asbestos product or company was Australian in origin. However such claims have not been successful to date. $^{10}$

\section{New Zealand Claims}

In New Zealand alternative compensation was sought though mental injury and exemplary damages claims.

$9 \quad G v G$ [1997] NZFLR 49 (HC).

10 James Hardy Ltd v Putt (27 May 1998) Court of Appeal New South Wales 40062/98. 


\section{Mental Injury (Nervous Shock) Claims}

As noted above the previous Acts had covered the physical and mental consequences of the injury or of the accident. Thus in $A C C v E^{11}$ an employee was covered by ACC for her nervous breakdown through attending a stressful management course. As she was covered by ACC a damages claim was barred under the previous Acts. However under the 1992 Act such nervous shock or stress claims were no longer barred and lawyers started to bring damages claims.

\section{$N$ Exemplary Damages Claims Added}

As claims for nervous shock started to be made, lawyers also added exemplary damages claims as well.

Admittedly this was to gain compensation, which was misusing the purpose of exemplary damages and if allowed to develop would have resulted in damages for personal injury being reintroduced to New Zealand.

Exemplary damages had always been awarded to punish the defendant and not to compensate the plaintiff. Furthermore they had generally been confined to cases of intentional harm in personal injury cases.

In the desire to find some remedy for those claimants who were not covered or were inadequately compensated by the 1992 Act lawyers argued that exemplary damages should be available in cases of "gross " negligence as well.

This argument succeeded in the case of McLaren Transport Ltd $v$ Somerville ${ }^{12}$ where $\$ 15,000$ was awarded to a man injured when a tyre being filled with air exploded.

\section{O Examples of Cases}

Following the 1992 Act the earliest cases filed were in 1993. In $F v$ Northland Health ${ }^{13}$ $\$ 150,000$ exemplary damages were claimed by a hospital employee who had been exposed to chemicals.

In $M v$ Wellington Area Health Board ${ }^{14} \$ 250,000$ exemplary damages and $\$ 75,000$ compensatory damages were claimed for mental trauma suffered as a result of the death of the plaintiff's wife in hospital.

$11 A C C v E[1992] 2$ NZLR 426 (CA).

12 McLaren Transport Ltd v Somerville [1996] 3 NZLR 424 (HC).

13 Fv Northland Health (17 March 1998) District Court Whangarei NP 868/93.

14 Mv Wellington Area Health Board (16 December 1994) High Court Wellington CP 205/93. 
Numerous cases followed and the sums claimed grew larger. In 1994 in Jackson v Bucher \& Ors,${ }^{15} \$ 1.5$ million exemplary damages were claimed for radiation damage from a negligent scan.

While the amounts claimed for exemplary damages grew the actual amounts awarded in any claim which reached the courts were much less. In Wilson $v$ Nightingale Trading the Court noted that "an examination of a range of decisions suggests four figures to be usual, five figures rare, and six unheard of". ${ }^{16}$

For example in $A v M^{17}$ only $\$ 20,000$ was awarded for marital rape.

The highest award seems to have been given in $G v G^{18}$ where $\$ 85,000$ was awarded for domestic and sexual abuse.

\section{P Curtailment of Exemplary Damages by the Court of Appeal}

Despite the low amounts actually awarded for those cases which reached the Court there was concern at the huge amounts being claimed and the intrusion of exemplary damages into negligent conduct. This led the Court of Appeal to signal the curtailment of such claims in Ellison v L. ${ }^{19}$

In that case $\$ 250,000$ exemplary damages had been claimed against a dentist. He had extracted a tooth but negligently left some packing in the wound. This caused the plaintiff some problems with infections until it was removed some nine months later.

The Court of Appeal effectively stopped exemplary damage claims for negligence when they said: ${ }^{20}$

We are prepared to accept for the sake of argument, though leaving the matter to be decided on another occasion, that in some cases of negligence exemplary damages may be awarded. But because negligence is an unintentional tort those cases are likely to be rare indeed. Exemplary damages are awarded to punish a defendant for high handed disregard of the rights of a plaintiff or for acting in bad faith or for abusing a public position or behaving in some other outrageous manner which infringes the rights of the defendant. Negligence simpliciter will never suffice.

The amounts claimed for exemplary damages were also limited. The Court said: ${ }^{21}$

\footnotetext{
15 Jackson v Bucher (19 September 1997) High Court Hamilton CP56/94.

16 Wilson v Nightingale Trading (4 August 1999) High Court Wellington CP 88/99 Durie J, 3.

$17 A v M[1991] 3$ NZLR 228 (HC).

$18 G v G[1997]$ NZFLR 49 (HC).

19 Ellison $v L$ [1998] 1 NZLR 416 (CA).

20 Ellison, above, 419, Blanchard J.

21 Ellison, above.
} 
We desire to make an observation about the level of damages claimed. Mrs Ellison has sought leave to bring a claim for $\$ 250,000$. Even if the conduct of the respondent had been outrageous and deserved to be marked by an award of exemplary damages, a claim of this size would be quite unrealistic. As far as we are aware, Judges in this country have restricted such awards to a mere fraction of the sum claimed here (for example, in McLaren Transport where apparently gross negligence in the inflating of a tyre caused serious injury $\$ 15,000$ was awarded). They have been right to do so. The marking out and punishment of outrageous behavior can be adequately achieved by a relatively modest penalty. It is to be remembered that such awards are not intended as compensation.

Legal advisors should be careful not to be associated with claims for amounts of damages which on any objective view are unattainable and give the appearance of being brought in terrorium.

The restriction on exemplary damages for negligence was continued in Bottrill $v A^{22}$ and Attorney-General $v$ Gilbert $^{23}$ where the Court of Appeal required conscious wrongdoing or subjective recklessness for such a claim to succeed. While the Privy Council overturned the Bottrill decision leaving the test at outrageous conduct the trend to bring exemplary damages in negligence cases has effectively ceased.

Furthermore the amounts now claimed for exemplary damages have decreased.

In $A v$ Bottrill ${ }^{24}$ Young $\mathrm{J}$ noted that "an award of $\$ 20000$ to $\$ 30000$ would stop virtually any claim for exemplary damages as there would be nothing left after deducting legal and other expenses".

\section{$Q$ Other Limitations by the Court of Appeal on Exemplary Damages}

\section{Criminal conduct}

The Court of Appeal has also shown its aversion to the proliferation of exemplary damages in that in Daniels $v$ Thompson ${ }^{25}$ it held that no exemplary damages could be awarded against a defendant for criminal conduct. In that case an imprisoned rapist was also being sued for exemplary damages by the victim.

The effect of the decision only lasted for a short period however as it was retrospectively overruled by the legislature through section 396 of the Accident Insurance Act 1998.

22 Bottrill v A [2001] 3 NZLR 622 (CA).

23 Attorney-General v Gilbert (14 March 2002) Court of Appeal CA 141/00.

24 Av Bottrill (19 March 1999) High Court Auckland CP 310/96 Young J.

25 Daniels v Thompson [1998] 3 NZLR 22 (CA). 


\section{Fatal claims}

The Court of Appeal in Re Chase ${ }^{26}$ had earlier also halted exemplary damages claims where the defendant had killed the injured person. Thus it is cheaper for a wrongdoer to kill than maim in New Zealand.

\section{Nervous shock claims}

The Court of Appeal has not shown the same aversion to the growth of nervous shock claims as can be seen from Queenstown Lakes District Council v Palmer ${ }^{27}$ where a husband suffered mental injury from seeing his wife drown in a rafting accident. He was not physically injured and his mental injury was not covered by ACC therefore his nervous shock damages claim was not barred.

However some limitations were placed on such cases by the Court of Appeal in Van Soest v Residual Health Management Unit. ${ }^{28}$ In that case the relatives of a number of people killed in botched surgical operations sued for nervous shock.

The Court held that to sustain such a claim the nervous shock had to be a recognisable psychiatric condition. In the Van Soest ${ }^{29}$ case none of the relatives could show that. There was only normal anger and grief that was insufficient.

The Court of Appeal however also noted other difficulties in such cases particularly for secondary victims who would also need to show relational proximity (ties of love and affection with primary victim), and temporal and geographic proximity to the accident or its aftermath to succeed.

\section{$R$ Other Proceedings as a Result of the 1992 Act}

In addition to the 1992 Act fuelling damages claims it also led to an increase in other proceedings.

\section{Reviews and appeals}

Since the 1992 Act the review and appeal process in the ACC Act has been dominated by reviews and appeals brought on by changes in the 1992 Act.

Reviews and appeals now usually concern decisions about:

- Work capacity assessments;

- Independence allowance assessments;

26 Re Chase [1989] 1 NZLR 325 (CA).

27 Queenstown Lakes District Council v Palmer [1999] 1 NZLR 549 (CA).

28 Van Soest v Residual Health Management Unit [2000] NZLR 179 (CA).

29 Van Soest $v$ Residual Health Management Unit, above. 
- The restricted definitions of personal injury or accident; and

- Work related gradual process disease or infection decisions.

These are all areas of dissatisfaction created by the 1992 Act.

\section{SUING ACC}

Attempts were also made to sue the ACC for damages in the way that it administered or failed to administer the Act.

These claims have generally not succeeded as they are generally met with three arguments:

- That section 89(7) of the Accident Rehabilitation and Compensation Insurance Act 1992 is to the effect that where a remedy by way of review and appeal was provided for the very matter under contention then no other remedy is available. This has even been applied to prevent judicial review proceedings. ${ }^{30}$

- That the bar on bringing proceedings for damages arising directly or indirectly out of personal injury covered by the Acts in section 14 of the Accident Rehabilitation and Compensation Insurance Act 1992 prevents the ACC being sued as the plaintiff's involvement with ACC only arises if the plaintiff has suffered a personal injury.

- That where negligence is alleged the Courts are reluctant to impose a duty of care on such a statutory compensation organisation.

However if the matter in issue is not amenable to relief from the review and appeal process or concerned misfeasance in a public office by the ACC then separate proceedings could be brought. ${ }^{31}$ However in Pearce v $A C C^{32}$ a claim against the ACC in negligence was struck out on the basis that there was no duty owed, that the equivalent of section 89 (7) of the Accident Rehabilitation and Compensation Insurance Act applied and also that the bar on bringing proceedings in the equivalent of section 14 of that Act for damages arising directly or indirectly out of the personal injury prevented such claims.

30 ACC v Wellington District Court (2000) 14 PRNZ 507 (HC).

31 See Rogers v ACC (23 December 1997) High Court Auckland CP538/96 Smellie J; King v ACC [1994] NZAR 159 (HC) or misfeasance in a public office.

32 Pearce $v$ ACC (1991) 5 PRNZ 297 (HC). 


\section{ALTERNATIVE PROCEEDINGS FUELLED BY DISSATISFACTION WITH THE 1992 ACT}

\section{A Bill of Rights}

To avoid the bar on proceedings for damages arising from personal injury, claims have been brought for compensation using the New Zealand Bill of Rights Act 1990. In Innes $v$ Wong ${ }^{33}$ it was accepted that such claims may not be barred by the ACC bar on proceedings for damages, as they were proceedings for public law compensation not damages. However this view has recently been doubted in Wilding $v A G,{ }^{34}$ where Young $\mathrm{J}$ considered that even Bill of Rights claims were caught by the ACC bar on proceedings for damages.

\section{B OSH Prosecutions}

In prosecutions for breaches of the Health and Safety in Employment Act 1992 it has been common practice to award a portion of fines to the injured worker. The reason given for this in Department of Labour $v$ Alexandra Holdings ${ }^{35}$ was that the ACC "would not adequately compensate" the injured employee now that lump sums were no longer available under the 1992 Act. However such awards may now decline given that lump sums of up to $\$ 100,000$ have been reintroduced by the Injury Prevention Rehabilitation and Compensation Insurance Act 2001 for new injuries occurring from 1 April 2002 onwards.

\section{Health and Disability Commissioner Act 1994}

Under this Act breaches of the Health and Disability Code of Rights can result in awards of up to $\$ 200,000$ in damages from the Human Rights Review Tribunal (formerly known as the Complaints Review Tribunal). Awards are made if the defendant acts in "flagrant disregard of the rights of the aggrieved person". ${ }^{36}$ As "flagrant disregard" indicates an easier test to fulfil than the "outrageous conduct" test for common law exemplary damages claims there may be an increase in claims to this tribunal.

\section{Employment Related Claims}

The 1992 Act excluded non-physical stress claims from ACC cover therefore damages claims were no longer barred. In addition claims could be brought for a breach of statutory duty under Health and Safety in Employment Act 1992. Surprisingly it has taken some time for such claims to come forward but there have been significant awards made lately in three cases:

33 Innes $v$ Wong [1996] 3 NZLR 238 (HC).

34 Wilding v AG (12 November 2002) High Court Wellington CP 12/02 Young J.

35 Department of Labour v Alexandra Holdings [1994] DCR 50 (DC).

36 Director of Proceedings $v O^{\prime}$ Neil [2001] NZAR 59 (HC). 
- Brickell v Attorney-General: ${ }^{37}$ stress from video taping horrific scenes as a police video operator;

- Benge v Attorney-General: ${ }^{38}$ stress from poor police staffing levels; and

- Gilbert $v$ Attorney-General: ${ }^{39}$ stresses from an excessive caseload forced on a probation officer.

Such claims are likely to continue particularly as work related stress has been included in the latest amendment to the Health and Safety in Employment Act 1992.

\section{E Consumer Guarantees Act 1993}

Another alternative for some claims, which are not covered by ACC, is through the Consumer Guarantees Act 1993. In $W v L^{40}$ a claim was made for unsatisfactory breast enlargements which did not have cover as medical misadventure.

\section{CONCLUSION}

There is no doubt that the "meaner and leaner" 1992 Act caused a substantial increase in damages claims by (1) creating dissatisfaction with the removal of lump sums and (2) providing the opportunities to sue by removing or limiting ACC cover for nervous shock, workplace stress personal injury, accident and medical misadventure to name but a few. This caused aggrieved claimants to seek adequate compensation elsewhere.

In Residual Health Management Unit $v$ Downie Priestly $\mathrm{J}$ in the High Court below had said the following: ${ }^{41}$

I rather suspect that at some future date courts will be tempted to provide remedies for victims of medical misadventure and systemic failures in hospitals over and above the benefits and support currently available under the Accident Compensation legislation.

For all sorts of complex social, fiscal and legislative reasons the compensation entitlements of the victims of negligence have fallen far short of the much-trumpeted recommendations of the 1967 Woodhouse Commission Report. Such a perception may well lead to the [c]ourts providing remedies which are not currently available in the same way that in recent times common law remedies have been

37 Brickell v Attorney-General [2000] 2 ERNZ 529 (HC).

38 Benge v Attorney-General [2000] 2 ERNZ 234 (HC).

39 Gilbert v Attorney-General (15 March 2002) Court of Appeal CA 141/00.

$40 \quad W v L$ (9 April 1997) District Court Auckland NP1381/95.

41 Residual Health Management Unit v Downie (11 December 2001) Court of Appeal CA 147/01, 3. 
extended to include victims of historic sexual abuse. It is never beyond the wit of judges to expand the common law in an innovative way without violence to its principles and precedent.

The Court of Appeal refrained from commenting on this statement and has certainly not developed exemplary damages as a remedy for inadequate ACC compensation. Nor is there any sign of willingness by the courts to create other remedies. Indeed the courts seem to be content to leave any perceived injustices to be dealt with by Parliament. In Wardle $v A C C^{42}$ Gendall $\mathrm{J}$ thought it unfair that interest was not payable on late payments by the ACC that this was "regrettable but it is a matter for Parliament".

\section{In Fitzpatrick $v$ ACC Middleton J said: ${ }^{43}$}

My concern is that the restrictions imposed by the legislation means that the decision in this case creates an injustice to this appellant whom I do not consider has the capacity for work within the definition.

However, as I have said, I consider that both the respondent and this Court are required by the legislation to accept the assessments.

It may be that the remedies will be increasingly sought not through common law but through using statutory bodies such as the Human Rights Review Tribunal or using breaches of statutory duties in the Health and Safety in Employment Act 1992 in employment related cases.

The Accident Insurance Act 1998, which replaced the 1992 Act, did little to change matters. It continued with the same "mean and lean" provisions that were in the 1992 Act. The only major change in the 1998 Act was in allowing private insurance companies to deal with workplace injuries. That however only lasted for one year before the incoming Labour and Alliance Government restored the ACC monopoly.

Had the insurance companies continued there may have been even more litigation through the pressure on such companies to reduce the number and duration of accident claims to preserve profits.

Now the 1998 Act has itself been replaced by the 2001 Act and it may be that pressure to litigate will evaporate entirely now that lump sums of up to $\$ 100,000$ have been reintroduced to ACC and the "tail" of long term claimants has been substantially reduced to what the ACC now considers a genuine pool of seriously injured claimants.

One can only hope that there will not be another ACC Act for some time so that some consistency and predictability in ACC claims can emerge.

42 Wardle v ACC (18 October 2002) High Court Wellington AP 134/02 Gendall J.

43 Fitzpatrick v ACC (30 March 2000) District Court Wellington DC 51/00 Middleton J, 5. 
However if the National Party regains power it seems likely that there will be increased privatisation through the reintroduction of insurance companies to the work and motor vehicle injury parts of the ACC scheme. If that happens and insurance companies adopt the same profit driven litigation practices seen in other common law countries then we will be, once again, in for another round of increased personal injury litigation. 
